\title{
Clinical profile of viral hepatitis in a tertiary health care centre of eastern India
}

\author{
Behera A. $K^{1}$, Jit B. $P^{2}$, Purohit $P^{3}$, Nahak $S . R^{4}$, Chhatar $S^{1}$, Marndi $C^{1}$, Mohapatra M. $K^{1}$, Bag $S^{5}$ \\ ${ }^{1}$ Department of Internal Medicine, Veer Surendra Sai Institute of Medical Sciences and Research (VIMSAR), Burla, \\ Sambalpur, Odisha, India, ${ }^{2}$ School of Life Sciences, Sambalpur University, Jyoti Vihar, Burla, Odisha, India, ${ }^{3}$ Sickle Cell \\ Clinic and Molecular Biology Laboratory, Veer Surendra Sai Institute of Medical Sciences and Research (VIMSAR), \\ Burla, Sambalpur, Odisha, India, ${ }^{4}$ Department of Pathology, Veer Surendra Sai Institute of Medical Sciences and \\ Research (VIMSAR), Burla, Sambalpur, Odisha, India, ${ }^{5}$ Director, Veer Surendra Sai Institute of Medical Sciences and \\ Research (VIMSAR), Burla, Sambalpur, Odisha, India.
}

Address for Correspondence: Dr Ashok Kumar Behera, Assistant Professor, Department of Medicine, Veer Surendra Sai Institute of Medical Sciences and Research (VIMSAR), Burla, Odisha, E-mail - bdr.ashok@yahoo.com

\begin{abstract}
Background: Viral hepatitis is epidemic to developing country like India. Infection with Hepatitis A virus, Hepatitis B virus and Hepatitis $\mathrm{C}$ virus is much more important so far as the disease severity, selection of treatment option and adverse outcome associated with the therapy is concerned. This study was undertaken to assess the clinical and laboratory profile of viral hepatitis with co-infection at a tertiary care centre. Material and Methods: Patients admitted in the hospital with presenting signs and symptoms of viral hepatitis were included. The clinical and haematological profiles were observed and entered in a pre-designed format. Data were extracted and analysed by one-way-analysis-ofvariance (ANOVA) and $p<0.05$ was considered statistically significant. Results: The mean age of the patients was $32.86 \pm 13.3$ years (range, 18-60 years). Eleven patients were positive for hepatitis-E where as 6 patients were co-infected with both hepatitis-A and hepatitis-E. The commonest presenting symptom was yellowness of eyes and urine that accounts in 19 patients followed by fever in 8 patients, abdominal pain in 5 patients and vomiting in 3 patients. The incidence of dengue and leptospirosis was found in one patient each. Two patients had died. Conclusion: Large cohort of patients with different hepatitis virus infections is necessary for better understanding of pathophysiology, clinical profile that will enable treatment regimen tools for the patients for single as well as different co-infection.
\end{abstract}

Keywords: Hepatitis, Fever, Jaundice.

\section{Introduction}

Viral hepatitis is epidemic to many developing countries including India [1]. Viral hepatitis is common, that occurs in epidemic and endemic forms [2,3]. Coinfection with Hepatitis-A virus, Hepatitis-B virus and Hepatitis- $C$ virus is a quite frequent due to their shared mode of transmission [4]. Hepatitis-E Virus (HEV) is the most common and important cause of acute clinical hepatitis in adult population [5]. The disease was experimentally designed as a clinical entity during large water borne epidemic in 1980. HEV, a positive single stranded ribonucleic acid virus (RNA) belongs to Hepeviridae family that affects primarily adults in

Manuscript received $6^{\text {th }}$ June 2016

Reviewed: $18^{\text {th }}$ June 2016

Author Corrected: $29^{\text {th }}$ June 2016

Accepted for Publication $16^{\text {th }}$ July 2016 comparison to the children [6]. Faecal oral route, blood transfusion, contaminated water and food supply are the major mode of transmission for hepatitis-A as well as $\mathrm{HEV}$ [7]. HEV is responsible for high mortality in pregnant woman (20-30\%) compared to general population. Co-infection is much more important so far as the disease severity, selection of treatment option and adverse outcome associated with the therapy is concerned [8]. Clinical severity, sign and symptoms, and development of complications are the predisposing factors that must needs attention from time to time.

Present study represents the clinical profile of different viral hepatitis from a tertiary care centre in eastern India. 


\section{Material and Methods}

The prospective study was conducted in the Department of Medicine, Veer Surendra Sai Institute of Medical Sciences and Research (VIMSAR), Burla from July to September in the year 2015 .

Twenty three adult patients admitted in the Department of Medicine were included in this study. A detail history and thorough physical examination was monitored from each patient. Patients were subjected to complete blood count, liver function tests and blood examination for $\mathrm{Hbs} \mathrm{Ag}$. Final outcome were recorded in the form of discharge or death.

Statistical Analysis- All data were analysed by GraphPad Instat version 3 for window and one way ANOVA was done to identify statistical significance between various categorical variables.

\section{Results}

Twenty three adult male patients were included in this study with mean age of $32.86 \pm 13.34$ (range, 18-60 years). The commonest presenting symptom in these patients was yellowish discolouration of eyes and urine accounting in 19 patients followed by fever ( 8 patients), abdominal pain ( 5 patients) and vomiting ( 3 patients).

The incidence of dengue and leptospirosis was accounts in one patient each. All the clinical presentation has been illustrated in

Figure-1. There was dramatic increment in the activity of liver enzymes with mean value $1344 \pm 1034$ U/L for aspartate transaminase (AST) and 1303 $\pm 1015 \mathrm{U} / \mathrm{L}$ for alanine transaminase (ALT). The mean serum bilirubin direct level was $8.76 \pm 4.89 \mathrm{mg} / \mathrm{dL}$. The mean haemoglobin level was found to be $11.51 \pm 2.44 \mathrm{~g} / \mathrm{dL}$ (range, $5-16 \mathrm{~g} / \mathrm{dL}$ ).

The detail haematological and biochemical parameters has been illustrated in Table-1. A mean total platelet count was found to be $270.39 \pm 108.1110^{3} / \mu \mathrm{L}$. Only two patients had died and rest patients were discharged after recovery.

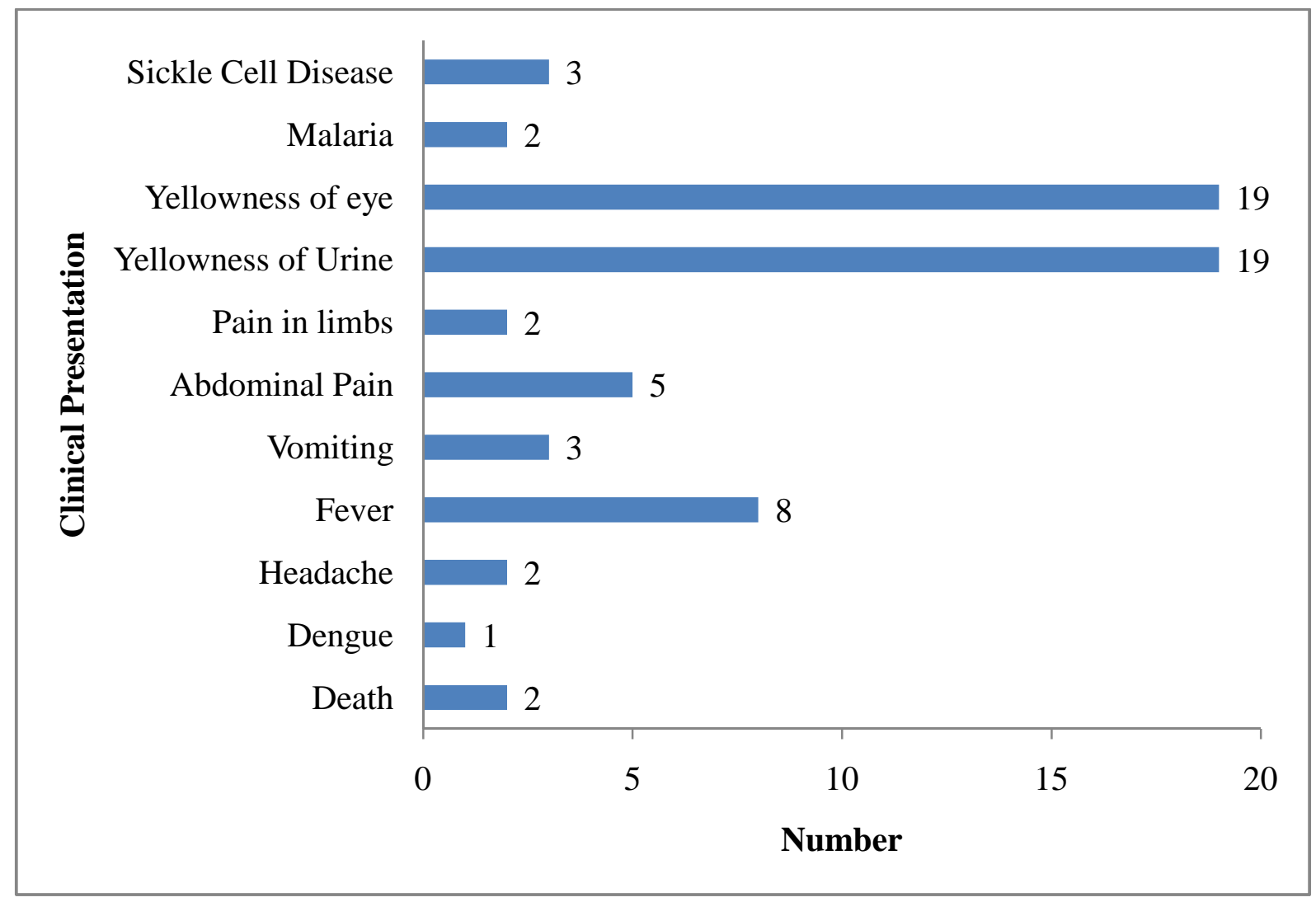

Figure 1: Clinical features of hospitalized patients with hepatitis virus $(n=23)$. 
Table 1: Hematological features of patients with hepatitis virus $(n=23)$.

\begin{tabular}{|c|c|c|c|}
\hline Parameters & MEAN \pm SD & Min-Max & Median \\
\hline Age in years & $32.86 \pm 13.34$ & $18-60$ & 24 \\
\hline Serum Transferrin $(\mathrm{mg} / \mathrm{dL})$ & $15.52 \pm 11.14$ & $2.24-38.1$ & 11.5 \\
\hline Bilirubin Direct $(\mathrm{mg} / \mathrm{dL})$ & $8.76 \pm 4.89$ & $34-3236$ & 820 \\
\hline Aspartate transaminase (U/L) & $1344 \pm 1036$ & $22-3292$ & 1198 \\
\hline Alanine transaminase (U/L) & $1303 \pm 1015$ & $105-496$ & 221 \\
\hline Alkaline phosphatase (U/L) & $242.17 \pm 111$ & $5-16$ & 12.2 \\
\hline Hemoglobin $(\mathrm{g} / \mathrm{dL})$ & $11.51 \pm 2.44$ & $32-475$ & 256 \\
\hline
\end{tabular}

Out of 23 patients, 13 patients belonged to 15-30 years of age, whereas 5 patients each belonged to 31-45 and > 45 years of age respectively. Sixteen patients had single infection where as other 7 patients had co-infection. In singe infection, hepatitis $\mathrm{A}$ and hepatitis $\mathrm{E}$ were found in 4 and 11 patients respectively.

Similarly in co-infection, both hepatitis A and E were found in 6 patients and two patients had both hepatitis B and E.

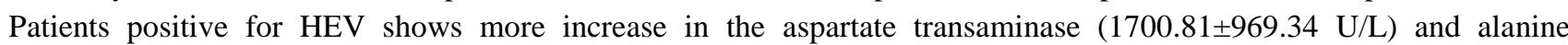
transaminase $(1628.36 \pm 741.67 \mathrm{U} / \mathrm{L})$ level compared to the other group though this difference did not reach statistical significance.

There was considerably decrement in the mean haemoglobin level in patients showing positive for the hepatitis A in comparison to the other groups.

The comparison of haematological and biochemical parameters across the groups has been shown in Table-2.

Table-2: Comparison of hematological and biochemical parameters in patients with different hepatitis infection.

\begin{tabular}{|c|c|c|c|c|c|}
\hline Parameters & $\begin{array}{l}\text { Positive for } \\
\text { Hepatitis- A }\end{array}$ & $\begin{array}{c}\text { Positive for } \\
\text { both Hepatitis } \\
\text { A and E } \\
\end{array}$ & $\begin{array}{l}\text { Positive for } \\
\text { Hepatitis E }\end{array}$ & $\begin{array}{c}\text { Positive for both } \\
\text { Hepatitis B and } \\
\text { E }\end{array}$ & $p$ value \\
\hline Number & 4 & 6 & 11 & 2 & \\
\hline Age (in years) & $23.8 \pm 8.0$ & $32.6 \pm 15.1$ & $33.5 \pm 12.8$ & $50.0 \pm 2.8$ & 0.159 \\
\hline $\begin{array}{l}\text { Serum transferrin } \\
(\mathrm{mg} / \mathrm{dL})\end{array}$ & $16.4 \pm 16.5$ & $15.5 \pm 11.7$ & $15.4 \pm 10.9$ & $14.5 \pm 5.4$ & 0.997 \\
\hline $\begin{array}{l}\text { Bilirubin direct } \\
(\mathrm{mg} / \mathrm{dL})\end{array}$ & $10.1 \pm 8.6$ & $9.7 \pm 4.9$ & $8.2 \pm 4.01$ & $10.1 \pm 6.1$ & 0.900 \\
\hline $\begin{array}{c}\text { Aspartate } \\
\text { transaminase }(\mathrm{U} / \mathrm{L})\end{array}$ & $1491.5 \pm 1662.6$ & $833.7 \pm 687.4$ & $1628.4 \pm 741.7$ & $270.0 \pm 263.0$ & 0.168 \\
\hline $\begin{array}{c}\text { Alanine } \\
\text { transaminase }(\mathrm{U} / \mathrm{L})\end{array}$ & $1060 \pm 1143.1$ & $1256.8 \pm 1094.5$ & $1700.8 \pm 969.4$ & $214.5 \pm 36.1$ & 0.268 \\
\hline $\begin{array}{c}\text { Alkaline } \\
\text { phosphatase (U/L) }\end{array}$ & $178.5 \pm 89.0$ & $311.3 \pm 159.1$ & $228.0 \pm 85.6$ & $241.0 \pm 21.2$ & 0.293 \\
\hline $\begin{array}{l}\text { Haemoglobin } \\
(\mathrm{g} / \mathrm{dL})\end{array}$ & $8.7 \pm 3.2$ & $12.1 \pm 2.4$ & $12.4 \pm 1.4$ & $10.5 \pm 2.05$ & $0.04 *$ \\
\hline Platelet count $\left(10^{3} / \mu \mathrm{L}\right)$ & $187.8 \pm 132.8$ & $250 \pm 124.3$ & $305.7 \pm 87.3$ & $302.5 \pm 71.4$ & 0.283 \\
\hline
\end{tabular}




\section{Discussion}

Co-infection with hepatitis-A virus, hepatitis-B virus and hepatitis- $C$ virus is a quite frequent due to their shared mode of transmission [4]. Faecal oral route, blood transfusion, contaminated water and food supply are the major mode of transmission for hepatitis-A as well as HEV [7]. Globally, there are approximately 20 million incidents of HEV infections every year.

The present study attempts to highlight the different clinical features and symptoms associated with the variability of hepatitis. Although illness is a self limiting factor, $<4 \%$ of death is predominant in general population [9]. In this study out of 23 patients, 8 patients were associated with co-infection to hepatitis, which is consistent with the study of Jabbar et al, [10]. The commonest presenting symptom was yellowness of eye and urine which accounts in 19 patients. This finding was again in line with the previous study of Toshniwal et al, [11] where as in the study of Modi et al, [12] they found the commonest presenting symptom were nausea / vomiting (88\%), anorexia (85\%), abdominal pain (49\%) and hepatomegaly (30\%).

Patients with co-infection showing positive for hepatitis-A and HEV have higher transaminases activity in comparison to the other groups, indicating the hepatic damage which was in line with Ziauddin et al,.[13] High incidence of patients positive for hepatitis E (11 patients) followed by hepatitis-A (4 patients) was observed.Increase in serum transaminase was correlated with the incidence of jaundice which is also consistent with the findings of Boda et al, [14] In this study [14], the authors found mild hepatomegaly $(40 \%)$, pedal oedema/ascites $(16 \%)$, and splenomegaly $(4 \%)$ in their patients which was not observed in our study.

In this study, singe infection, hepatitis A and HEV were found in 4 and 11 patients respectively. Similarly in coinfection, both hepatitis $\mathrm{A}$ and $\mathrm{HEV}$ were found in 6 patients and two patients had both hepatitis B and HEV which is comparable to the findings of Modi et al, [12] revealed that all the age groups within 12-60 years are susceptible to hepatitis $E$ infection. In the study of Sudhamsu et al, [15] the acute hepatitis associated with the thickening of gall bladder which was not observed in our patients. In the study of Zhang et al, [16] who found a total of $10.0 \%$ patient died where as in our study the mortality was found in only two patients. Patients showed mortality was infected with hepatitis A and HEV. Although the predominant cause of this mortality is unknown, however these two patients were previously affected by sickle cell disease and one of them was affected by malaria during hospitalization. Mortality was not seen in patients with co-infection, which is in consistent with the findings of Murthy et al. [17] Tong et al, [18] found 7.0\% of their patients had skin rash and $19.0 \%$ had arthalagia which was not seen in our patient. In our study, 21 patients were recovered within the one month of illness; where as in the findings of Tong et al, [15] $85.0 \%$ of patients were recovered by three months.

\section{Conclusion}

Viral hepatitis is the most common cause of jaundice. In this study, yellowness of eye and urine was the most common symptom. Two patients had died. The incidence of $\mathrm{HEV}$ is the most predominant that accounts in 11 patients. Patients' positive for coinfection of both hepatitis A and HEV accounts for 6 patients and followed by hepatitis $\mathrm{B}$ and HEV in two patients. Twenty one patients were recovered within one month of illness. In conclusion further research is required for better understanding of pathophysiology, clinical profile that will enable treatment regimen tools for the patients for single as well as different coinfection.

Funding: Nil, Conflict of interest: None initiated, Permission from IRB: Yes

\section{References}

1. Suri AD, Jain RK, Jain SC. Study of Jaundice profile in Pregnancy in tertiary care centre in central India. International Journal of Medical Research and Review. 2014; 2 (1): 3-7.doi:10.17511/ijmrr.2014.i01.003.

2. Sharma RS, Datta KK, Datta M. Field trial on village level surveillance of epidemic prone diseases and its evaluation. Swasth Hind. 1987; 31: 301-303 and 319.

3. Indrani K, Prasad SP. Shrestha J, Pal SR. Etiological Spectrum of acute sporadic viral hepatitis amongsts adults in Chandigarh. Indian J. Med Res.1990;91:91-93.

4. Crespo J, Lozano JL, de la Cruz F et al., Prevalence and significance of hepatitis $\mathrm{C}$ viremia in chronic active hepatitis B. American Journal of Gastroenterelogy. 1949; 89 (8):1147-51 
5. Purcell RH, Emerson SU. Hepatitis E: an emerging awareness of an old disease. J Hepatol 2008:48(3):494503.

6. Khuroo MS. Study of an epidemic of non-A, non-B hepatitis, Possibility of another human hepatitis virus distinct from post-transfusion non-A, non-B hepatitis. Am J Med. 1980; 68: 818-24.

7. Viswanathan R. Infectious hepatitis in Delhi (195556): a critical study-epidemiology. Indian J Med Res. 1957; 45: 1-29.

8. Chi-Jen C, Shou-Dong L. Hepatitis B virus/hepatitis $\mathrm{C}$ virus co-infection: epidemiology, clinical features, viral interactions and treatment. Journal Gastroenterol Hepatol. 2008; 23(4):512-20.

9. Khuroo MS, Rustgi VK, Dawson GJ, et al. Spectrum of hepatitis E virus infection in India. J Med Virol.1994; 43(3):281-6.DOI:10.1002/jmv.1890430316.

10. Jabbar A, Pathan M. Clinical Profile of Viral Hepatitis at a Tertiary Care Centre in Rural Maharashtra: An Observational Study. IOSR Journal of Dental and Medical Sciences (IOSR-JDMS). 2015; 14(10): 26-28.DOI: 10.9790/0853-141072628.

11. Toshniwal HK. Clinical profile of viral hepatitis - A study of 1569 cases. The Indian Practitioner. 1990; XLIII: 567-573.
12. Modi TN, Patel SA, Mirani KM, et al. A Study of Clinical Profile and Outcome in Acute Viral Hepatitis E. Indian Journal of Clinical Practice. 2013; 23(10):635-37.

13. Ziauddin, Ali S, Saeedi MI. Frequency and clinical presentations of hepatitis $\mathrm{B}$ and $\mathrm{C}$ virus co-infection in tertiary care hospital. Rawal Medical Journal. 2013; 38(1): 11-14.

14. Boda S, Makineni VM, Chinni AK, et al., Clinical and laboratory profile of hepatitis E during an outbreak in Nellore: A tertiary care centre experience. Int J Sci Stud 2015;3(2):132-138. DOI:10.17354/ijss/2015/227

15. Sudhamsu KC. Ultrasound findings in acute viral hepatitis.Kathmandu Univ Med J(KUMJ).2006;4:415-8.

16. Zhang S, Wang J, Yuan Q, et al. Clinical characteristics and risk factors of sporadic Hepatitis E in central China. Virol Journal. 2011; 8: 152. DOI: $10.1186 / 1743-422 x-8-152$.

17. Murthy KAS, Kiran PK, Hakeem H. A study of viral hepatitis $\mathrm{E}$ infection in a tertiary care hospital in Mysore, South india. Open forum infectious disease. 2014 Jun 19;1(1):ofu036. doi: 10.1093/ofid/ofu036.

18. Tong MJ, el-Farra NS, Grew MI. Clinical Manifestations of Hepatitis A: Recent Experience in a Community Teaching Hospital. Journal of infectious disease. 1995;171 suppl 1: S15-8.

\section{How to cite this article?}

Behera A. K, Jit B. P, Purohit P, Nahak S. R, Chhatar S, Marndi C, Mohapatra M. K, Bag S. Clinical profile of viral hepatitis in a tertiary health care centre of eastern India. Int J Med Res Rev 2016;4 (7):12761280.doi:10.17511/ijmrr.2016.i07.34. 